\title{
APELACJA TEODORETA DO PAPIEŻA LEONA
}

By zrozumieć apelację Teodoreta do Leona Wielkiego, trzeba w zarysie przypomnieć sobie rolę odegraną przez tego papieża w sporach chrystologicznych V wieku. Bez tego nie sposób ani zrozumieć szczególnej pozycji Leona, ani nadziei, jaką on i jego wystapienie wzbudzały w biskupach antiocheńskich, zaatakowanych przez aleksandryjskiego patriarchę, Dioskura.

\section{ZARYS DZIAEALNOŚCI DOKTRYNALNEJ PAPIEŻA LEONA}

Papież Leon Wielki był najwybitniejszym papieżem V wieku. Jego działalność obejmowała wszystkie dziedziny życia kościelnego. Zaangażowanie Leona nie zaczęło się $\mathrm{z}$ chwilą wstąpienia na tron rzymski. Już za pontyfikatu Celestyna I (422-432) widzimy go jako diakona, pełniącego różne odpowiedzialne funkcje. Wtedy to, na jego prośbę, Jan Kasjan - mnich syryjski żyjący w Marsylii, napisał De incarnatione Domini contra Nestorium libri VII, dedykowane właśnie jemu. Widzimy go też na polu polityki kościelnej jako pomocnika i pośrednika papieża w wielu sprawach (np: Juwenalisa, Juliana z Eklanum). Za następcy Celestyna, Sykstusa III, pełnił dalej swoją funkcję biorąc udział w życiu państwa (pośredniczył między Aecjuszem i Albinusem). W czasie tej misji umiera papież i jego następcą zostaje wybrany właśnie on, Leon (440-461). Nowy papież rozpoczął aktywną działalność ogólnokościelną, której celem było - między innymi - umocnienie prymatu Rzymu. Nie zapomniał też o duszpasterstwie w swojej rzymskiej diecezji, zostawiając po sobie dużą liczbę listów i kazań (96 Mów i 173 Listy).

W pasterskiej trosce Leona dużo miejsca zajęły kwestie doktrynalne i walka $\mathrm{z}$ herezjami. Szczególną rolę odegrał on w czasie kontrowersji monofizyckiej. Wysłał wtedy dwa listy: Tomus ad Flavianum ${ }^{1}$ i Epistula $165^{2}$ (te się zachowa-

1 Por. Concilium Chalcedonense, Epistula papae Leonis ad Flavianum episcopum Constantinopolitanum de Eutyche (= Tomus ad Flavianum), tłum. T. Wnętrzak, w: Dokumenty Soborów 
ły), w których wykłada ortodoksyjną naukę o wcieleniu i o unii natur w Chrystusie. Oba listy zostały przyjęte jako wyznanie wiary katolickiej, a List do Flawiana został uznany na Soborze Chalcedońskim (451) za „kolumnę przeciw naukom heretyckim i dla umocnienia dogmatów prawdziwej religii" ${ }^{3}$.

W swoich wywodach papież czerpał argumentację i symbolikę z dzieła Jana Kasjana na temat wcielenia ${ }^{4}$. Poprzez legatów uczestniczył w latrocinium ephesinium w 449 roku; on też, na wiadomość o jego przebiegu jako pierwszy go potępił nadając mu nazwę latrocinum (rozbój), która przyjęła się w historii. W jego imieniu legaci przewodniczyli Soborowi Chalcedońskiemu. W celu utrzymania kontroli nad wykonaniem decyzji soborowych ustanowił apokryzjariuszy, czyli stałych legatów w Konstantynopolu. Papież Leon odrzucił 28 kanon Soboru Chalcedońskiego, dotyczący patriarchatu konstantynopolitańskiego i jego prawnego i honorowego prymatu na Wschodzie. Był jednym z pierwszych papieży mających jasną świadomość wlasnego posłannictwa i szczególnej roli w Kościele, o czym świadczą chociażby jego kazania ${ }^{5}$.

W niniejszym artykule interesuje nas postawa papieża w okresie sporu monofizyckiego w latach 448-451, a konkretnie wszystko to, co dotyczy apelacji, jaką od decyzji synodu w Efezie z 449 r. wniósł do niego Teodoret z Cyru.

1. List do Flawiana (Tomus ad Flavianum) i jego reperkusje. Jak zaznaczyliśmy na początku artykułu, aby zrozumieć decyzję Teodoreta i jego odwolanie do papieża Leona, trzeba prześledzić wcześniejsze wydarzenia. Nie było to bowiem pierwsze odwołanie do Leona w ramach nowej kontrowersji. Już na samym początku sporu wokół doktryny monofizytów Eutyches odwoływał się, m.in. do papieża Leona. Jednakże biskup Rzymu nie chciał zabierać glosu w sprawie znanej mu tylko $z$ jednej strony. Zresztą, wkrótce po odwołaniu się przez Eutychesa, również patriarcha Flawian wysłał swój list do Rzymú ${ }^{6}$. W piśmie tym zreferował papieżowi doktrynę Eutychesa i powody jej potępienia. To umożliwiło Leonowi zabranie głosu w tej sprawie. Zawiadomił Flawiana, że postara się jak najszybciej wydać orzeczenie. I rzeczywiście, już 13 VI 449 r. wysłał list do patriarchy Konstantynopola, który przeszedł do historii jako List dogmatyczny do Flawiana (Tomus ad Flavianum).

Powszechnych. Tekst grecki, laciński, polski, t. 1: (325-787), red. A. Baron - H. Pietras, ŹMT 24, Kraków 2001 (= DSP I), 196-213.

${ }^{2}$ Por. PL 54, 1155-1190.

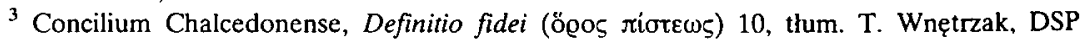
I 220-221.

${ }^{4}$ Por. De incarnatione Domini contra Nestorium, ed. M. Petschening, CSEL 17, Wien 1888, 235-291.

5 Por. Leo Magnus, Sermones, PL 54, 141-468, thum. K. Tomczak, POK 24, Poznań - Warszawa - Lublin 1957.

6 Papież Leon zaznaczyl, iż dziwi się, „że został wysłany tak późno”, por. Tomus ad Flavianum 1, DSP I 196-197. 
W rozdziale II tego Listu papież Leon konstatuje, że do udowodnienia Eutychesowi herezji wystarcza przyjęcie „wspólnego i ogólnego wyznania wiary, jakie składa cała społeczność wiernych. Wyznaje ona, ze wierzy w Boga, Ojca Wszechmogącego i w Jezusa Chrystusa, Syna Jego jedynego a Pana naszego, który narodził się z Ducha Świętego i z Maryi Panny" ". Stąd, stwierdza papież, że „Eutyches, który wydawał się [być] godnym czci jako prezbiter, okazal się wielce nieroztropny i za mało wykształcony"8. W dalszej części papież daje pełny wykład wiary: najpierw stwierdza jasno kwestionowany punkt doktryny (podwójne narodziny i dwie natury), następnie ukazuje myśl i zamiar Boży w tajemnicy wcielenia. Wychodząc $\mathrm{z}$ tych założeń powraca do tematu i w ich świetle rozważa własności obu narodzin i natur. Przypomina jednocześnie, że realność ciała w Chrystusie jest jednym z podstawowych zalożeń doktryny, ustalonym $\mathrm{w}$ sporze $\mathrm{z}$ doketami:

„Jeden Syn Boży jest i Słowem i Ciałem [...]. Kościół katolicki taką wiarą żyje i taką wiarą wzrasta; wierzy, że [w Chrystusie Jezusie] nie ma człowieczeństwa bez prawdziwej Boskości, ani Boskości bez prawdziwego człowieczeństwa"”.

Całą naukę św. Leona można sprowadzić do czterech punktów ${ }^{10}$. Po pierwsze, w Chrystusie jest tylko jedna osoba: jeden i ten sam jest prawdziwym Synem Boga i prawdziwym Synem Człowieka. Po drugie, w tej jednej osobie są dwie natury, bóstwo i człowieczeństwo, bez zmieszania, każda z nich zachowuje swoje cechy. Po trzecie, jeżeli jedna $z$ natur posiada własną właściwość i jest ona niezależna od drugiej, to mimo to nie jest ona poza ich jednością, która jest stała (nie zmienia to zależności tej cechy od danej natury jako pierwszej przyczyny). Po czwarte, od tej unii zależy communicatio idiomatum, to znaczy możliwość orzekania właściwości jednej natury o drugiej, np. Jednorodzony Syn Boga został ukrzyżowany i pochowany.

List, oprócz pouczenia dogmatycznego, zawierał jeszcze rozstrzygnięcia dyscyplinarne. Papież m.in. żądał, aby Eutyches potępił „wszystko, co błędnie mniemał - dla pełnego zadośćuczynienia - żywym głosem i własnoręcznym podpisem" "11. Jednocześnie zaleca:

„Wprawdzie grzeszących powściąga sprawiedliwośc, ale nawróconych miłosierdzie nie odrzuca"12.

W związku z decyzją cesarza, zwołującego wbrew stanowisku papieża sobór do Efezu, Leon wyprawił swoich legatów, aby uczestniczyli w soborowym spotkaniu $w$ jego imieniu.

\footnotetext{
7 Tamzie 2, DSP I 196-197.

8 Tamże 1, DSP I 196-197.

9 Tamże 5, DSP I 206-211.

${ }^{10}$ Por. B.J. Otten, Manual of the History of Dogmas, London $1922^{3}$.

1 Tomus ad Flavianum 6, DSP I 210-211.

12 Tamże, DSP I 212-213.
} 
Na soborze w Efezie patriarcha Dioskur, który objął przewodniczenie, nie dopuścił ani do odczytania listu Papieża do Ojców synodu, ani do odczytania Listu do Flawiana. Kiedy na pierwszej sesji, wśród wyzwisk i tumultu mnichów egipskich oskarżających przeciwników Eutychesa o nestorianizm, ekskomunikowano i deponowano Flawiana, pobito go i jego zwolenników, kiedy ogłoszono Eutychesa prawowiernym nauczycielem wiary, deponowano jego przeciwników i zmuszano biskupów do podpisania monofizyckiego wyznania wiary, legaci papiescy uciekli z Efezu i poinformowali Leona o przebiegu obrad. Ten, jak wspomnieliśmy, nazwał sobór latrocinium, uznał go za nieważny i potępił jego uchwały. Mimo że Zachód przyjął decyzje Papieża, na Wschodzie monofizytyzm zwyciężał. Cesarz Teodozjusz II, popierając uchwały synodu zbójeckiego, deponował biskupów ortodoksyjnych i mianował nowych. Jednak szybka śmierć cesarza zmieniła diametralnie sytuację. Tron objęła cesarzowa Pulcheria, siostra i współregentka Teodozjusza II od 415 roku. Razem z mężem Marcjanem zaproponowała papieżowi zwołanie soboru do Nicei w celu uporządkowania sytuacji. Na soborze tym, który zebrał się ostatecznie w Chalcedonie, jednym z podstawowych dyskutowanych dokumentów był List do Flawiana.

$\mathrm{Na}$ drugim posiedzeniu odczytano list Papieża. Został on przyjęty przez Ojców soboru jako „wiara apostołów, słowa Piotra, który przemówił przez Leona". Po oczyszczeniu z zarzutów niektórych biskupów, po depozycji i ekskomunice Dioskura i Eutychesa, na polecenie cesarskiej pary, w oparciu o pismo papieża Leona, ułożono nowy symbol, jasno określający unię natur w Chrystusie. Biskupi Wschodu użyli terminologii opracowanej przez św. Cyryla Aleksandryjskiego i teologów wschodnich. W uchwalonych kanonach przyjęli wyraźnie, obok Credo Nicejsko-Konstantynopolitańskiego i listów św. Cyryla, także List do Flawiana Leona Wielkiego jako pełny i katolicki wyklad wiary ${ }^{13}$.

2. Stosunek Teodoreta do wykładu wiary zawartego w Liście do Flawiana papieża Leona. Po synodzie „zbójeckim”, kiedy cesarz Teodozjusz zaczął wprowadzać jego uchwały siłą, jedną z pierwszych represjonowanych osób był Teodoret. Wokół niego biskupi podpisywali nowe wyznanie wiary, on zaś pozostał wierny swojej nauce. W tym momencie tylko jeden patriarcha Kościoła nie pogodził się z decyzjami latrocinium - papież Leon. Nie tylko nie uznał uchwał soboru, ale i przesłał na Wschód swoje wyznanie wiary, wyznanie zgodne z poglądami Teodoreta.

Biskup Cyru przyjął więc Tomus ad Flavianum $\mathrm{z}$ radością, jeśli nie z entuzjazmem. Dał temu wyraz w kilku listach. I tak, rekomenduje ten wykład wiary patrycjuszowi Anatolowi jako pismo, w którym ,zachował on [Leon] ducha

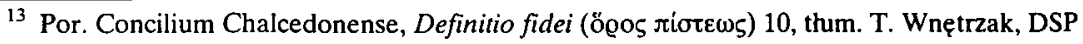
I 220-221. 
apostolskiego"14, i w którym Teodoret znalazł „naukę świętych i błogosławionych proroków, apostołów, tych, co po nich głosili Ewangelie i, naturalnie, zgromadzonych w Nicei Ojców świętych"15. Pisząc zaś do samego papieża Leona apelację od wyroku depozycji i banicji uchwalonego w Efezie (449), podkreślał, m.in. dwie rzeczy. Po pierwsze, ścisłość wypowiedzi Papieża ${ }^{16}$, która dokładnie i bez niedomówień wyświetliła obie prawdy - o Bóstwie i o człowieczeństwie Jezusa Chrystusa oraz o naturze człowieczeństwa pełnego (doskonałego), „pod każdym względem podobnego naszej [naturze]”"17; z tą tylko różnica, ,że Jezus Chrystus był wolny od wszelkiego grzechu, gdyż źródłem jego nie jest natura, ale wolna wola"18. Po drugie, list Leona bez niedomówień stwierdza jedność Jezusa Chrystusa: „jest jeden Jednorodzony Syn Boga"19, jak i konieczność przyjęcia człowieczeństwa dla realizacji planów zbawienia. Teodoret nie ukrywał swego podziwu dla nauczania Papieża i przyznawał, „że wysławialiśmy łaskę Ducha Świętego, który przemawiał waszymi [tj. św. Leona] ustami" ${ }^{20}$.

Jednocześnie Teodoret uważał, że dla niego samego dowodem ortodoksji jest zgodność jego nauczania $\mathrm{z}$ nauczaniem biskupa Rzymu. I w tym wypadku pomocny będzie tu list do patrycjusza Anatola. Stwierdzał w nim bowiem wyraźnie, przesyłając patrycjuszowi list papieża, by przypomniał sobie i przekonał się o zgodności $z$ sobą tych nauk ${ }^{21}$. W dwóch innych listach, pisząc do żołnierzy $\mathrm{i}$ do mnichów $\mathrm{z}$ Konstantynopola, Teodoret wyraźnie i niedwuznacznie powołał się znowu na zgodność swojego nauczania $\mathrm{z}$ pismami Papieża, traktując je jako kryterium ortodoksji swojego przepowiadania Ewangelii. I tak, stwierdzając autentyczność swojego nauczania i przywołując na świadków uznane autorytety kościelne z przeszłości ${ }^{22}$, umieścił między „Ojcami

14 Theodoretus, Epistula 121, SCh 111, 84, thum. J. Radożycki: Teodoret z Cyru, Listy, Warszawa 1987, 205. Przy numeracji listów stosowane są cyfry lacińskie lub arabskie. Numery lacińskie dotyczą tzw. Collectio Patmensis, natomiast arabskie tzw. Collectio Sirmondiana, zachowanej u Migne'a (PG 83, 1173-1494) i poszerzonej o odkryte później listy. Obie kolekcje zostały wydane w serii „Sources Chrétiennes” przez Y. Azema, por. SCh 40 (Paris 1955), SCh 98 (Paris 1964), SCh 111 (Paris 1965).

${ }_{15}$ Epistula 121, SCh 111, 84, Radożycki s. 205.

16 Por. Epistula 113, SCh 111, 58, Radożycki s. 195.

17 Por. tamże.

18 Tamzie.

19 Tamże.

20 Tamże, SCh 111, 60, Radożycki s. 196.

${ }^{21}$ Por. Epistula 121, SCh 111, 84, Radożycki s. 206: „Dołączam do mojego listu jeden z tych, które on [Leon] wysłał do Efezu, aby Wasza Szlachetność przeczytawszy go, przypomniała sobie to, cośmy po wielokroć głosili w kościołach, przekonała się o zgodności ze sobą tych nauk".

22 Wśród nich wymienia Bazylego Wielkiego, Grzegorza z Nazjanzu, Amfilocha z Ikonium, Damazego z Rzymu, Ambrożego z Mediolanu, Cypriana z Kartaginy, Atanazego i Aleksandra, Eustacjusza, Melecjusza, Flawiana, Efrema, Jana, Attyka, Ignacego Antiocheńskiego, Polikarpa, Ireneusza, Justyna, Hipolita, por. Epistula 146, SCh 111, 189-190, Radożycki s. 247-248. 
wiary" także biskupa Leona (jedynego żyjącego w tym katalogu!), jako tego, „który dał nam swoim nauczaniem taki wzór wiary" ${ }^{23}$. W liście do żołnierzy mówiąc o konieczność przyjęcia przez Chrystusa pełnego czlowieczeństwa zacytował jako argument przekonywujący pismo Leona. Kiedy, składając apelację do biskupa Rzymu, prosił jednocześnie jednego z jego legatów, Renata, o wstawiennictwo, stwierdził wyraźnie, że dowodem jego prawowierności jest zgodność prawd, których nauczał, z wypowiedziami Papieża:

„Znalazłem je także w pismach najświętszego i najświątobliwszego arcybiskupa Rzymu, mojego pana Leona"24.

Daje też wyraz swojej radości $z$ wierności nauczania $\mathrm{z}$ tymi zasadami - „wielbiłem Pana swojego wszechrzeczy, że pozostaję w zgodności z jego nauką apostolską"25.

Zachowane więc Listy pozwalają dość łatwo ustalić stosunek Teodoreta do nauczania Leona. Biskup Cyru uważał je za potwierdzenie swojej słuszności i za autorytatywna definicje dogmatyczna. Przyjął List do Flawiana i inne pisma papieża Leona ${ }^{26}$, jako ostateczne nauczanie i w pełni ortodoksyjny wykład wiary. Swoje własne prace uznał za słuszne, gdyż były zgodne $\mathrm{z}$ wypowiedziami Papieża.

\section{TEODORET WOBEC BISKUPÓW RZYMU}

Dopiero teraz możemy zająć się bezpośrednio samą apelacją Teodoreta, jak i wynikającą z niej relacją do Biskupa Rzymu. Jak zostało przypomniane, samo odwołanie ma miejsce w szczególnym momencie, a istotnym jego elementem jest stosunek Teodoreta do nauki chrystologicznej Leona przesłanej uczestnikom synodu w Efezie z 449 roku. Ten aspekt „dogmatyczny”, jak i fakt wsparcia w najtrudniejszych chwilach trzeba mieć na oku oceniając wypowiedzi Biskupa Cyru. Są one bowiem ,funkcjonalne”, to znaczy zawsze w kontekście polemiki, w której jedynym gwarantem prawowierności wydawał się być Leon Wielki.

1. Sukcesja apostolska biskupów Rzymu. Teodoret jest jednym z ostatnich wielkich teologów greckich ery patrystycznej, jak i jednym $z$ ostatnich teologów

${ }^{23}$ Tamże, SCh 111, 190, Radożycki s. 248.

${ }^{24}$ Epistula 116, SCh 111, 72, Radożycki s. 201.

25 Tamże.

${ }^{26} \mathrm{Z}$ listu, który skierował Teodoret do patrycjusza Anatola wynika, że bylo ich więcej, por. Epistula 121, SCh 111,84, Radożycki s. 205-206: „,albowiem pisma najmilszego Bogu i najświątobliwszego arcybiskupa wielkiego Rzymu, pana Leona, skierowane do świętej pamięci Flawiana $i$ innych biskupów zgromadzonych w Efezie [...]. Prawdą bowiem jest, że w pismach swoich zachował on [...]. Dołączam do mojego listu jeden z tych, które on wysłał do Efezu". 
Kościoła Wschodniego, podkreślających tak bardzo autorytet i szczególne miejsce Rzymu w hierarchii Kościoła. Niedwuznacznie łączył on pozycję Miasta $\mathrm{z}$ apostolskim następstwem biskupa Rzymu po św. Piotrze, choć wśród tytułów do „przewodzenia” na równi stawia grób Piotra jak i Pawła, co sugerowałoby łączenie prymatu z ,relikwiami apostołów”, bez powoływania się na obietnicę zawartą w Ewangelii Mateusza. W tym kierunku skłania się także uzasadnienie apelacji. W swoim liście do papieża Leona wyraźnie porównał swoje odwołanie do ,apelacji” Pawła do Piotra w sprawie przestrzegania Prawa przez chrześcijan, a nie jako zwrócenie się do „najwyższego w Kościele autorytetu jurysdykcyjno-doktrynalnego". O swoim liście mówi więc, jak o posłaniu kogoś, kto śpieszy do Piotra, by uzyskać odpowiedź.

Stolicę Rzymską nazywa „apostolskim tronem"27. Czy ta sukcesja po Piotrze jest podstawą prymatu? Rzym zawiera groby ojców i nauczycieli we wierze - Piotra i Pawła, którzy tu ponieśli męczeńską śmierć - „stamtąd i dzisiaj” [promień wiary] oświetla ziemię ${ }^{28}$. Powtórzmy więc pytanie, czy sukcesja, w naszym rozumieniu, po św. Piotrze jest podstawą prymatu? Piotr i Paweł występują równorzędnie, a powołanie się na nich ma charakter odwołania do ich świadectwa wiary bez wyraźnego nawiązania do „prymatu” Piotra. Są oni tymi, którzy razem „dodali blasku waszemu [papieża Leona] tronowi i stanowią ukoronowanie waszych bogactw"29.

Teodoret często nazywa Rzym „stolicą apostolską”, powołując się na jego „skarb apostolski”, jak i apostolską władzę tamtejszych biskupów. Ale czy oznacza to prymat w naszym rozumieniu? Brak jest przekonujących dowodów, a posiadane fragmenty tekstów można równie dobrze wytłumaczyć w ramach rodzącej się idei „pięciu” patriarchatów, czyli stolic Piotrowych, do których należy w pierwszym rzędzie Rzym, ale nie tylko on. Ustawienie na równi „wiary Piotra” i „wiary Leona” oraz odwołanie do tej wiary jako podstawy apelacji może sugerować, że nasze wątpliwości mają podstawę w myśleniu Teodoreta. Powtórzmy jeszcze raz - bez wątpienia Rzymska Stolica zajmuje szczególne miejsce i pozycję, ale czy można mówić tutaj o prymacie - w tej kwestii trzeba być bardzo ostrożnym. Reasumując, głównym powodem, dla którego prymat ma przynależeć do biskupa Rzymu jest apostolski charakter jego stolicy i ,wiara apostolska" samego Leona.

${ }^{27}$ Epistula 113, SCh 111, 56, Radożycki s. 194. Trzeba jednak wyraźnie zaznaczyć, że stwierdzenie „apostolski” w odniesieniu do biskupa Rzymu nie jest wyłączne. Pisząc bowiem do patriarchy Konstantynopola Proklosa (Epistula XV, SCh 40, 87, Radożycki s. 45) mówi o ,apostolskiej myśli” biskupa tego miasta; w odniesieniu zaś do Flawiana pisze, jak u Leona, o „apostolskiej wierze” (Epistula 11, SCh 98, 38, Radożycki s. 87). Co więcej, w kolejnym liście do Flawiana pisząc o stolicy w Antiochii wyraźnie nazywa ją „tronem od wielkiego Piotra” (Epistula 86, SCh 98, 230, Radożycki s. 167). Określenie „apostolski tron” nie jest więc używane wyłącznie w odniesieniu do Rzymu.

${ }^{28}$ Por. Epistula 113, SCh 111, 58, Radożycki s. 195.

29 Tamze. 
2. Teodoret wobec Biskupów Rzymu jako strażników Tradycji. Do zrozumienia stosunku Teodoreta wobec biskupów Rzymu konieczne jest poznanie funkcji Tradycji w nauczaniu Biskupa Cyru. W wielu listach jasno określił swoją postawę wobec Tradycji reprezentowanej przez Ojców soboru w Nicei. Już te poglądy dotyczące małego wycinka „nauki Ojców wiary” pozwalają odpowiedzieć na problem. Stwierdzal on wprost, że zachowanie depozytu Objạwienia jest połączone nierozerwalnie ze związkiem tego nauczania z nauką „Ojców z Nicei” jako normą i prawem. Jednocześnie nazywał ją „pokarmem apostolskim” traktowanym na równi z Pismem Świętym. Odejście od tej Tradycji traktowal jako herezję, a poglądy jej przeciwne jako bezbożność. Tak więc „depozyt wiary” dla Teodoreta pokrywał się nie tylko $\mathrm{z}$ nauczaniem Pisma Świętego, ale i z nauką głoszoną przez Ojców soboru w Nicei.

Czy jednak pojęcie Tradycji wiąże tylko z Ojcami soboru? Sformułowanie zagadnienia w Liście do Florencjusza patrycjusza wskazuje na rozciągnięcie pojęcia Tradycji na tych, co „objaśniali pisma apostołów i proroków”, świętych przewodników w wierze. Kilkakrotnie też podał ich katalog. I tu rzecz charakterystyczna. Nie tylko uznał jednego z papieży, Damazego, za Nauczyciela wiary, ale wymienił wśród nich żyjącego współcześnie $z$ nim aktualnego biskupa Rzymu Leona! Przyjmował jego nauczanie z tą samą powagą, jak nauczanie świętych Ojców w wierze, męczenników, nauczycieli prawdy, twierdząc, że jak i oni „rozsiewa promień prawdziwej nauki” dając wzór wiary Ojców. Uważał więc biskupa Leona za żywego świadka Tradycji.

Czy jest to stosunek do samego Leona czy do Stolicy Rzymskiej? Analizując sformułowania użyte przez Teodoreta w Liście do Leona i porównując je $\mathrm{z}$ innymi jego wypowiedziami, można przyjąć, że uważał obronę wiary i dziedzictwa Ojców za pierwszy obowiązek każdego wierzącego, w tym dla biskupów Rzymu. Jednak łączność z „Ojcami w wierze” ma dodatkowe znaczenie, jako oparcie się na tych, którzy nie zbłądzili. I prawdopodobnie dlatego sądzil, że zgodność jego nauczania z nauczaniem papieża Leona i ,innych świadków w wierze" 30 jest, wystarczającym dowodem na prawdziwość jego nauki, nie jest bowiem ona „nowinką teologiczną”. Pisma samego Leona zawierały treści nie tylko zgodne z Pismem Świętym, ale i z Tradycją przekazaną i ujętą przez Sobór Nicejski. Sobór był dla niego wyrazicielem Tradycji Apostolskiej postawionej na równi $z$ autorytetem Biblii.

Jednakże tekstem klasycznym, mówiącym o stosunku Teodoreta do biskupów Rzymu, jak i rozumienia przez niego ich funkcji i powiązania jej z Tradycją było, naszym zdaniem, zakończenie listu apelacyjnego do papieża Leona. Prosi on w nim Biskupa Rzymu, by wszystkie swoje siły oddał trosce o wiarę i ,strzegł w Kościołach w nienaruszonym stanie dziedzictwa naszych ojców". To jest jego

${ }^{30}$ Por. przypis 22. 
podstawową funkcją „Biskupa Rzymu”, za to właśnie ma odebrać w przyszłości nagrodę od Pana.

Leon, biskup Rzymu, jest wiec zdaniem Teodoreta żywym strażnikiem Tradycji, którego zadaniem jest strzec wiary w Kościele. Za to rozliczy go Pan.

3. Jurysdykcyjny autorytet Leona jako biskupa Rzymu. Dla Teodoreta, papież jest nie tylko strażnikiem wiary i Tradycji. Jego urząd sięga dalej. I to chyba najbardziej wyróżniało Biskupa Cyru pośród biskupów Wschodu. Dla Teodoreta biskup Rzymu posiadał autorytet jurysdykcyjny w Kościele. Powtórzmy, autorytet, nie władzę.

W Liście do Renata, legata papieskiego, stwierdził wyraźnie, że biskup Rzymu ma prawo przewodzić całemu Kościołowi:

„Dlatego proszę Waszą Świętość, aby przekonała najświętszego i najświątobliwszego arcybiskupa Rzymu, aby użył swej apostolskiej władzy i nakazal, abym przybył na wasz synod. Albowiem ta święta stolica ma wiele tytułów do przewodzenia Kościołom całego świata, a nade wszystko ten, ze pozostała z dala od heretyckiej zgnilizny i nie zasiadł na niej nikt mający przeciwne przekonania, lecz tylko taki, który zachowal nienaruszony skarb apostolski. My bowiem jesteśmy gotowi podporządkować się waszemu orzeczeniu, jakiekolwiek ono będzie, ufając waszemu sprawiedliwemu sądowi ${ }^{31}$.

Dlatego Teodoret wyrażał wolę podporządkowania się decyzji Leona. Według niego, właśnie w Rzymie można znaleźć „lekarstwo dla ukojenia ran zadanych Kościołom". Rzym jest bowiem „apostolskim tronem” posiadającym prymat. $\mathrm{O}$ tym, że autorytet ten i prymat jest także jurysdykcyjny, swiadczyła zarówno apelacja od depozycji wydanej w Efezie, jak i samo jej sformułowanie. Teodoret odwołał się do Leona, do jego „rzetelnego i sprawiedliwego wyroku”. W związku z tym ,arcybiskup Rzymu” ma prawo wezwać biskupa do siebie, na swój synod, na sąd. Jednocześnie Biskup Cyru prosi o odpowiedź, czy ma się podporządkować decyzji efeskiej i pogodzić z depozycją. Traktuje decyzję Leona jako ostateczną, pośrednią pomiędzy decyzją świecką cesarza i kościelną synodu w Efezie a samym Bogiem. Dla tej decyzji deklaruje posłuszeństwo i zapowiada, że od niej nie będzie się odwoływał. W Kościele od Soboru Nicejskiego i Konstantynopolitańskiego ${ }^{32}$ obowiązywała zasada nieingerencji patriarchów jednej prowincji w sprawy innej. Dla Teodoreta wynikało stąd, że ostateczną instancją mającą charakter jurysdykcyjny jest jego własny patriar-

${ }^{31}$ Epistula 116, SCh 111,70 , Radożycki s. 200. Oryginalny tekst podkreślonego przez autora

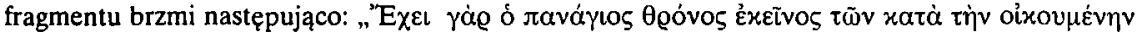

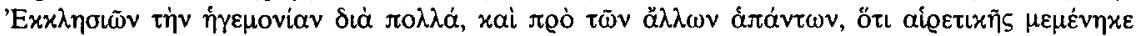

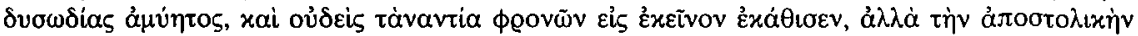

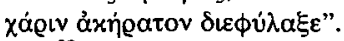

32 Por. Concilium Nicaenum I, can. 5 (częściowo) i can. 6, DSP I 30-33, oraz Concilium Constantinopolitanum I, can. 2, DSP I 70-73. 
cha $^{33}$. Jednak sam, w cytowanym Liście 86 łamie tę zasadę odwołując się do decyzji patriarchy Konstantynopola, a nie własnej diecezji, Antiochii. Idąc dalej, można założyć, że odwołanie do Leona jest spowodowane brakiem jakiegokolwiek innego autorytetu „patriarchalnego”, do którego mógłby się odwołać Teodoret. Własny jego metropolita zdradził go dla ratowania swojej pozycji. Patriarcha Konstantynopola zginął, a całe zamieszanie było skutkiem działania biskupa „stolicy błogosławionego Marka” ${ }^{34}$ - Dioskura. W tej sytuacji jedynym pozostałym ,apostolskim tronem” był biskup Rzymu, co sugerowałoby że uważał jego status ,jurysdykcyjny” za wyjątkowy w Kościele (ale wyjątkowy w tej właśnie konkretnej sytuacji). Do tego pozycja, jaką poprzez swój „autorytet” posiadał Leon, uzasadniała odwołanie. Stąd też prosił go o interwencję i wysłuchanie jego wysłanników.

Apostolski charakter decyzji biskupa Rzymu dostrzega jednak Teodoret nie tylko w ingerencji w sprawy efeskie. Uważa je za normalną działalność biskupa Rzymu. Tak samo postępuje rzymski patriarcha i w innych kwestiach dotyczących Kościola i wiary. Czy Teodoret przez prymat Rzymu rozumie to, że ma on przewodzić Kościołom całego świata? Czy prymat ten ma charakter także jurysdykcyjny, o czym miałaby świadczyć sama apelacja, jak i stwierdzenie nieodwoływalności tego wyroku? Czy można by więc to uznać za przyznanie biskupowi Rzymu w Kościele najwyższego autorytetu jurysdykcyjnego? Teodoret zwraca się wprost do papieża, przez jego archidiakona, by „także Kościoły Wschodnie znalazły się pod skrzydłami waszej troskliwości”. Czy oznacza to uznanie władzy papieża nie tylko na Zachodzie, ale i w całym Kościele, uznanie pełne, zarówno w dziedzinie doktrynalnej, jak i jurysdykcyjnej? Wydaje się, że zachowane teksty nie pozwalają na takie stwierdzenia. Odnoszą się one do konkretnej „nadzwyczajnej sytuacji” i w tej nadzwyczajnej sytuacji sięga się po nadzwyczajne środki. Autorytet Biskupa Rzymu jest więc wyjątkowy, szczególny, także $w$ aspekcie jurysdykcyjnym, ale nie jest to „urząd”, lecz „autorytet”, ${ }^{\text {,35 }}$. Fragment Listu $86^{36}$ wyraźnie nie daje innym

${ }^{33}$ Por. Epistula 86, SCh 98, 228-230, Radożycki s. 166: „Albowiem błogosławieni Ojcowie, zgromadzeni w owej stolicy [Konstantynopolu] rozgraniczyli, w pełnej zgodności z tymi, którzy zebrali się w Nicei, diecezje, i każdej przyznali prawo decydowania o swoich sprawach, wyraźnie zabraniając komuś z jednej diecezji wtrącania się w sprawy drugiej. Biskup Aleksandrii zatem powinien zarządzać tylko sprawami Egiptu, a każda diecezja swoimi”; zob. też przypis 32.

${ }^{34}$ Epistula 86, SCh 98, 230, Radożycki s. 167.

35 Inaczej mówiąc i używając specyficznie rzymskiego terminu bliskiego tamtym czasom auctoritas.

${ }^{36}$ Por. Epistula 86, SCh 98, 228-230: „Prosimy Twoją Świętość [Flawiana] aby stanęła w obronie atakowanej wiary podjęła walkę o kanony, które zdeptano. Albowiem błogosławieni Ojcowie, zgromadzeni w owej stolicy rozgraniczyli, w pełnej zgodności z tymi, którzy zebrali się w Nicei, diecezje i każdej przyznali prawo do decydowania o swoich sprawach, wyraźnie zabraniając komuś $z$ jednej diecezji wtrącania się $w$ sprawy drugiej. Biskup Aleksandrii winien zatem zarządzać tylko sprawami Egiptu, a każda diecezja swoimi. Tymczasem on nie chce stosować się 
patriarchom prawa do ingerencji w sprawy innych prowincji. Sam List 86 skierowany do Patriarchy Konstantynopola przez biskupa Cyru, a więc z patriarchatu Antiochii, z prośbą o interwencję wobec patriarchy Aleksandrii, jest odstępstwem od przyzywanej reguły!

4. Misja Biskupa Rzymu w Kościele. W swoim Liście do papieża Leona Teodoret daje stosunkowo jasny i wyraźny wykład na temat, jak pojmuje prymat papieży, skąd wypływa szczególna pozycja, którą zajmuje w Kościele biskup Rzymu. Jak sam stwierdza „wszystkie racje wskazują na to, że do was [Leona] należy prymat". Jest to prymat, na wzór prymatu Piotra w gronie apostołów, auctoritas a nie urząd. Co wywyższa Stolicę Rzymską? I tu wylicza Biskup Cyru argumenty uzasadniające jej prymat. Można je podzielić na dwie grupy: przyczyny historyczne i przyczyny natury religijnej.

I tak, Rzym jaśnieje pośród innych miast, przewyższając je rozmiarami „wielkością, liczbą ludności”. Jest też „stolicą świata” i „wydało dziś jeszcze panującą władzę". Nadało też imię całemu państwu. Racją jego prymatu może więc być pierwszeństwo, jako pierwszeństwo historycznej stolicy. Ale nie tylko to wyróżnia Miasto.

Bóg, zdaniem Teodoreta, obdarzył Rzym jeszcze wspanialszymi darami duchowymi. Ozdabia go wiara, której świadkiem jest jeden z Apostołów (por. $\mathrm{Rz} \mathrm{1,8).} \mathrm{Ta} \mathrm{wiara} \mathrm{jest} \mathrm{i} \mathrm{dziś} \mathrm{w} \mathrm{nim} \mathrm{obecna,} \mathrm{i} \mathrm{dziś} \mathrm{w} \mathrm{nim} \mathrm{rozkwita.} \mathrm{Ale}$ nade wszystko jest to stolica św. Piotra i św. Pawła, do tej pory oświetlona ich wiarą. Obaj apostołowie pochodzili, co prawda, ze Wschodu i tam przede wszystkim głosili Ewangelię, ale ta para właśnie w Rzymie „na Zachodzie przyjęła $\mathrm{z}$ odwagą koniec swego życia i stamtąd dziś oświetla ziemię" ${ }^{37}$. To oni dodali blasku Stolicy Rzymskiej stanowiąc ukoronowanie jej bogactw. Ich tron trwa tam aż do dziś i aktualnym ich następcą jest papież Leon.

Ale za tym duchowym aspektem „przewodniczenia Rzymu” przemawia jeszcze jeden, najpoważniejszy argument, który zadecydował o szczególnej pozycji Biskupów Rzymu, a mianowicie oni jako jedyni, zachowali nienaruszony skarb wiary. To jest przede wszystkim, zdaniem Teodoreta, tytułem ich prymatu:

„[Wasza Stolica] pozostała $z$ dala od heretyckiej zgnilizny i nie zasiadł na niej nikt mający przeciwne przekonania, lecz tylko taki, który zachowal nienaruszony skarb apostolski"38.

do tych zasad, lecz miesza do wszystkich spraw stolicę błogosławionego Marka, dobrze przy tym wiedząc, że wielkie miasto Antiochia ma tron od wielkiego Piotra, który był nauczycielem błogosławionego Marka oraz pierwszym w gronie apostołów i koryfeuszem. Co do nas to jesteśmy świadomi wielkości naszego tronu, ale znamy też siebie i wlasne ograniczenia. Od początku bowiem uczyliśmy się pokory apostołów. Twoją Swiątobliwość natomiast prosimy, aby nie patrzyła obojętnym okiem, jak depcze się święte kanony, lecz z zapałem bronila swiętej wiary".

${ }^{37}$ Epistula 113, SCh 111, 58, Radożycki s. 195.

38 Epistula 116, SCh 111, 70, Radożycki s. 200. 
Troska apostolska biskupa Rzymu jest funkcją spełnianą w całym Kościele w obronie wiary. Stąd jego wystąpienia wobec manichejczyków, stąd gorliwość w sporze $\mathrm{z}$ monofizytami. Autorytet jego dotyczy wszystkich spraw związanych $\mathrm{z}$ wiarą $\mathrm{i}$ jest to głos Tradycji, w nim żywej, co pozwala mu na orzekanie, czy nauka zgodna jest $\mathrm{z}$ przekazem apostolskim.

Posłannictwo biskupów Rzymu, w rozumieniu Teodoreta, obejmuje sobą cały świat. Nauczanie papieża jest bowiem „promieniem prawdziwej nauki” rozsiewanym wszędzie. Stąd też prośba Biskupa Cyru, aby „także Kościoły Wschodnie znalazły się pod skrzydłami waszej [Leona] troskliwości”. W zasięgu oddziaływania Stolicy Rzymskiej jest więc cały Kościół, stąd „błagamy i zaklinamy Twoją Świętość, aby broniła Kościołów Bożych nękanych przez burze" ${ }^{\prime 39}$. Jak widać autorytet ten ma znaczenie nie tylko w sprawach wiary, ale i jurysdykcyjnych.

\title{
LA LETTERA DI TEODORETO RIVOLTA AL PAPA LEONE
}

\author{
(Sommario)
}

La lettera di Teodoreto rivolta al Papa Leone, chiamato il Grande, è un apellatio. Il vescovo di Ciro, quando fu condannato durante il sinodo nel Efesio nell'anno 449, fu costretto a trovare un apoggio ecclesiale e teologico. Per questo Teodoreto di Ciro nella sua corrispondenza di quell periodo parla spesso di approvazione della decisione dogmatica e ecclesiastica da parte di Leone presa nei confronti del monofisitismo ed esplicata nel Tomos ad Flavianum. Argomentazione esibita, il modo nel quale Teodoreto prese quella decisione, danno la possibilità di capire chi era - per lui - il vescovo di Roma, quale era il suo posto specifico e privilegiato nella Chiesa, e anche quale era la missione del Succesore di Pietro secondo l'insegnamento del Signore.

${ }^{39}$ Epistula 113, SCh 111, 58, Radożycki s. 196. 